\title{
Lateral menisküs allogreft transplantasyonu
}

\section{Lateral meniscus allograft transplantation}

\author{
Uğur Haklar ${ }^{1}$, Serkan Aykut ${ }^{2}$ \\ ${ }^{1}$ Bahçeşehir Üniversitesi Tıp Fakültesi, Ortopedi ve Travmatoloji Anabilim Dalı; Liv Hospital, Ulus, İstanbul \\ ${ }^{2}$ Sağıık Bilimleri Üniversitesi, Metin Sabancı Baltalimanı Kemik Hastalıkları Eğitim ve Araştırma Hastanesi, \\ Ortopedi ve Travmatoloji Kliniği, İstanbul
}

\begin{abstract}
Menisküsler bir diz eklemi için önemli ve gerekli dokulardır; menisküs yırtığı ameliyatlarından sonra korunamadıklarında ve büyük kısımları alındığında, eksilmeleri oranında diz artrozlarına neden olmaktadır. Menisküs eksiklikleri durumunda olası artrozları engellemek için en kabul görmüş tedavi yöntemi, günümüzde menisküs allograft transplantasyonlarıdır. Literatür bilgilerine göre, başarılı transplantasyonlardan sonra yaklaşı 20 yıl kadar artrozun önlendiği bildirilmektedir. Mediyal ve lateral menisküsler farklı anatomilere sahiptir; dolayısıyla, transplantasyon ameliyatları da farklı ameliyat teknikleri gerektirir.
\end{abstract}

Anahtar sözcülkler: diz; lateral menisküs; allogreft transplantasyonu
Menisci are precious and necessary components of a knee joint. After meniscal tear surgeries, knee arthritis occurs proportionate to removed menisci volumes in surgeries. Menisci allograft transplantation is the most accepted treatment for preventing knee arthritis due to lack of menisci tissue. Literature states that successful transplantations prevent arthritis of the knee for up to 20 years. Medial and lateral menisci have different anatomies; therefore, their transplantations require different surgical methods.

Key words: knee; lateral meniscus; allograft transplantation

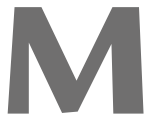

enisküs, bilindiği gibi, diz ekleminin önemli dokularından birisidir. Menisküslerin, tibiofemoral ekleme gelen yükün dağılımı, femur ve tibia kemiklerinin diz eklemindeki adaptasyonu, kıkırdakların beslenmesi ve kayganlığı gibi önemli fonksiyonları vardır. ${ }^{[1-4]}$ Menisküs dokusu, dizin fonksiyonunu sağlamak için mutlak gerekli olan bir dokudur; vücudumuzda başka bir bölgede bulunmayan özel yapısı nedeni ile, yaralanması durumunda başka bir doku ile replase edilememektedir. Diz ekstansiyonda iken mediyal kompartmanın yüklenmesinin \%50'sini mediyal menisküs alırken, bu oran lateral kompartmanda lateral menisküs için \%70'tir. ${ }^{[5]}$ Diz fleksiyona geldiğinde bu $\% 70$ 'lik oran $\% 85^{\prime}$ e çıkar. ${ }^{[5]}$ Lateral menisküs daha fazla kuvvet yüklendiğinden, yapılan total lateral menisektomi sonrası karşılıklı yüzeyler arası temas alanı \%40-50 oranında azalarak eklem yüzeylerinde \%200-300'lere çıkan bir temas gücü oluşturur. ${ }^{[3,6]}$ Menisektomiler sık uygulanan cerrahi girişimlerdir. Çoğunlukla menisküsün \%50'den daha azı alınarak uygulanır. Ancak, kova sapı tipi yırtıklarda menisküsün \%50'den fazlasının alınması söz konusu olduğunda, menisküs allogreft transplantasyonları (MAT) gündeme gelir. ${ }^{[6,7]}$ Menisküs anatomilerinin iyi bilinmesi MAT cerrahisinde önemlidir. Mediyal ve lateral menisküsler birbirinden yapı olarak çok farklıdır. Mediyal menisküs kapsüle daha sıkı bağlanan bir yapı olmasının yanında, tibiaya yapışma yerleri birbirine uzaktır. Buna karşın, lateral menisküsun ön ve arka boynuzlarının tibiaya yapışma yerleri birbirine yakındır ve kapsüle çok sıkı bağlanmaz. ${ }^{[2]}$ Bunun nedeni, dizin rotasyon merkezinin mediyal tibia platosunun ortasında olmasıdır. Diz tam ekstansiyondan tam fleksiyona gelirken yaklaşık $20^{\circ}$ 'lik bir rotasyon yapar ve lateral femur kondili lateral tibia platosunun üzerinde yaklaşık 20 mm'lik bir hareket yapar. ${ }^{[3]} \mathrm{Bu}$ hareket, lateral tibia platosunun konveks olması ve lateral menisküsün kapsül ve çevre dokulara sıkı bağlı olmamasının yardımı ile gerçekleşmektedir. Bu harekete yardımcı olan diğer önemli yumuşak dokular; posterolateraldeki sıkı ve dinamik bağlar, tensor fasya lata ve rotasyonda önemli görevi olan popliteofibuler komplekstir. Bu nedenlerdendir ki lateral MAT tekniği mediyal MAT tekniğinden faklılıklar gösterir.

- İletişim adresi: Prof. Dr. Uğur Haklar, Bahçeşehir Üniversitesi Tıp Fakültesi, Ortopedi ve Travmatoloji Anabilim Dalı; Liv Hospital, Ulus, İstanbul Tel: 0212 - 9998099 e-posta: dr@ugurhaklar

- Geliștarihi: 1 Mart $2018 \quad$ Kabul tarihi: 1 Mart 2018 


\section{TARIHÇE}

İnsanlarda ilk MAT ameliyatı, Milachowski ve ark. tarafından 1984 yılında yapılmış, bu olgu ve sonradan yapılan olgular ile ilgili deneysel ve klinik çalışmaların sonuçları 1989 yılında yayımlanmıştır. ${ }^{[8]}$ Deneysel çalışmalarında, 15'er koyundan oluşan ilk gruba liyofilize gama sterilize allojenik menisküs, diğer gruba ise derin dondurulmuş menisküsleri transplante etmişlerdir. illk grupta tam remodelizasyon elde edilirken, ikinci grupta remodele olmayan ancak fonksiyonel olarak tam olan menisküsleri elde ettiklerini bildirmişlerdir. Klinik çalışmalarında ise genel olarak, derin dondurulmuş allogreftler ile daha iyi sonuçlar elde edilmiştir. Takiben, endikasyonlar, greft koruma yöntemleri, cerrahi teknik ve eşlik eden kondral ve ligamentöz yaralanmalar durumunda yaklaşım konuları ile ilgili çok sayıda deneysel ve klinik çalışma yapılmıştır. ${ }^{[2,3]}$ Ancak, literatürün çoğunluğu kontrollü olmayan geriye dönük olgu serilerinden oluşmakta ve yüksek seviye çalışmalara ihtiyaç duyulmaktadır. ${ }^{2,4,9,10]}$ Ülkemizde ise MAT, 1990-1992 yılları arasında, dört dizde kurutulmuş mediyal menisküs allogreftleri kullanılarak, Binnet ve ark. tarafından yapılmıştır. ${ }^{[11]}$ Binnet ve ark., bu tekniğin istenilen başarı düzeyine erişememesinin nedenini, o dönemde taze donmuş allogreft teminindeki güçlüklerden dolayı allogreftin kurutulmuş tipte olmasına, kemik blokları ile fikse edilmemesine bağlamış ve olgularının uzun dönem sonuçlarını bildirmişlerdir. Ulusal literatürde bu konudaki ilk derleme makale 1997 yılında yayımlanmıştır. ${ }^{[12]}$

\section{ENDIKKASYONLAR VE GEREKLILIKLER}

MAT için uygun endikasyonların başında, total ya da subtotal menisektomi yapılmış hastalar gelir. Bu yöntemin uygulanabilmesi için stabil olan ya da stabilitesi sağlanabilecek bir diz gereklidir. Ön çapraz bağ (ACL) yaralanması ya da eşlik eden bağ yaralanmalarının olduğu kombine yaralanmalarda, bu yapılar da aynı seansta ya da daha önceden düzeltilmelidir. ${ }^{[13]}$ Aynı şekilde, diz ekleminde dizilim bozukluğunun olmaması ya da düzeltilmesi gereklidir. Özellikle karşılıklı yüzeylerde kondral lezyonların olmaması gereklidir; bundan dolayı, kondral yüzeyler ameliyat öncesi çekilen 3.0 tesla manyetik rezonans (MR) incelemeleri ile veya bir önceki artroskopi incelemesi ile net olarak değerlendirilmelidir. Dizi etkileyen kollajen doku hastalıkları gibi sistemik hastalıkların varlığında MAT kontrendikedir. Yapılan rekonstrüksiyonda temel amaçlar başlıca üç grupta incelenebilir. Bunlardan ilki fonksiyonelliktir. Yaptığımız transplantasyon fonksiyonel olmalı ve yerleştirilen menisküs görevini yapabilmelidir. İkincisi, şekil ve yapı açısından orijinalinin taklit edilebilme yeteneğidir; ve son olarak da, yaptığımız rekonstrüksiyon güvenilir olmalıdır. Güvenilirlik, hem biyomekanik hem de biyolojik açıdan olmalıdır.

\section{KLINIK DEĞERLENDIRME VE GÖRÜNTÜLEME}

Parsiyel menisektomi yapılan hastaların semptomları genellikle düzelir (ortalama 2-15 yıllık bir dönemde), ancak hasta daha sonra eklem hattında ağrı, aktiviteye bağlı şişme, yaygın ağrı ve yürüme bozuklukları şeklinde tipik şikâyetler ile başvurur. ${ }^{[2,7]}$ Hastaların öyküsü alınırken, yaralanma mekanizması ve eşlik eden yaralanmalar ile daha önceki tedaviler sorgulanmalıdır. Öncelikle hastanın boyu, kilosu ve obezite durumu değerlendirilmelidir. Eklem hareket açıklığı da not edilir. Eklem hareket açıklığının değerlendirilmesinde minimum karşı diz gibi ekstansiyon ve $125^{\circ}$ fleksiyon olması istenir. Fizik muayenede, alt ekstremite dizilim bozukluğunun öncelikli olarak değerlendirilmesi gerekir. Diz çevresi eski ameliyat izleri, önceki tedaviler hakkında fikir verir. Palpasyonda, eklem hattında hassasiyet, femoral tibial kondil kenarında ağrı ve kemiksi değişiklikler, eklem içi effüzyon bulguları değerlendirilmelidir. Bir diğer önemli nokta da osteofitlerin değerlendirilmesidir. Özellikle hareket kısıtlılığı olan dizlerde osteofitler araştırılmalı ve iyi değerlendirilmelidir. Total ya da parsiyel menisektomi yapılmış uzun süre transplantasyon için bekleyen hastalarda osteofit oluşumları, cerrahi sırasında yeni konulacak menisküs dokusunun yerleşimine engel olabilir, hatta dokuyu zedeleyebilir. Hastaların tam ekstansiyonda yük vererek AP ve yük vermeden $45^{\circ}$ fleksiyonda lateral diz ve aksiyel patellofemoral grafileri çekilir. Ek olarak eklemi daha ayrıntılı değerlendirebilmek için $45^{\circ}$ fleksiyonda yük vererek P-A grafi de istenir. Hastanın mekanik aks ile ilgili dizilim bozukluğu var ise alt ekstremite ortoröntgenografisi çekilmelidir. Başarılı bir cerrahi planlama için ileri görüntüleme araçlarından MR değerlendirmesi eklem içi ve dışı sorunları anlama açısından mutlak gereklidir. Eklemdeki kıkırdak defektlerinin, subkondral kemiğin ve kalan menisküs ile çapraz bağların durumunun belgelenmesi amacıyla, özellikle yüksek çözünürlüklü (3.0 Tesla) MR ile değerlendirmeler gereklidir (Şekil 1).

\section{GREFT SEÇIMi, BOYUTLANDIRMA, STERILIZASYON VE KORUNMASI}

MAT için uygun donörün seçimi, önemli ve hassas konulardan bir tanesidir. Donör seçiminde kanser, yasa dışı ilaç kullanımı, enfeksiyon, ileri yaş, osteoporoz, steroid kullanımı, kronik böbrek hastaları gibi geniş bir grup elendiğinde, elde edilen kadavraların yalnızca \%1-2'lik kısmından menisküs allogrefti elde edilebilir. Ayrıca, hazırlanmaları sırasında da doku 

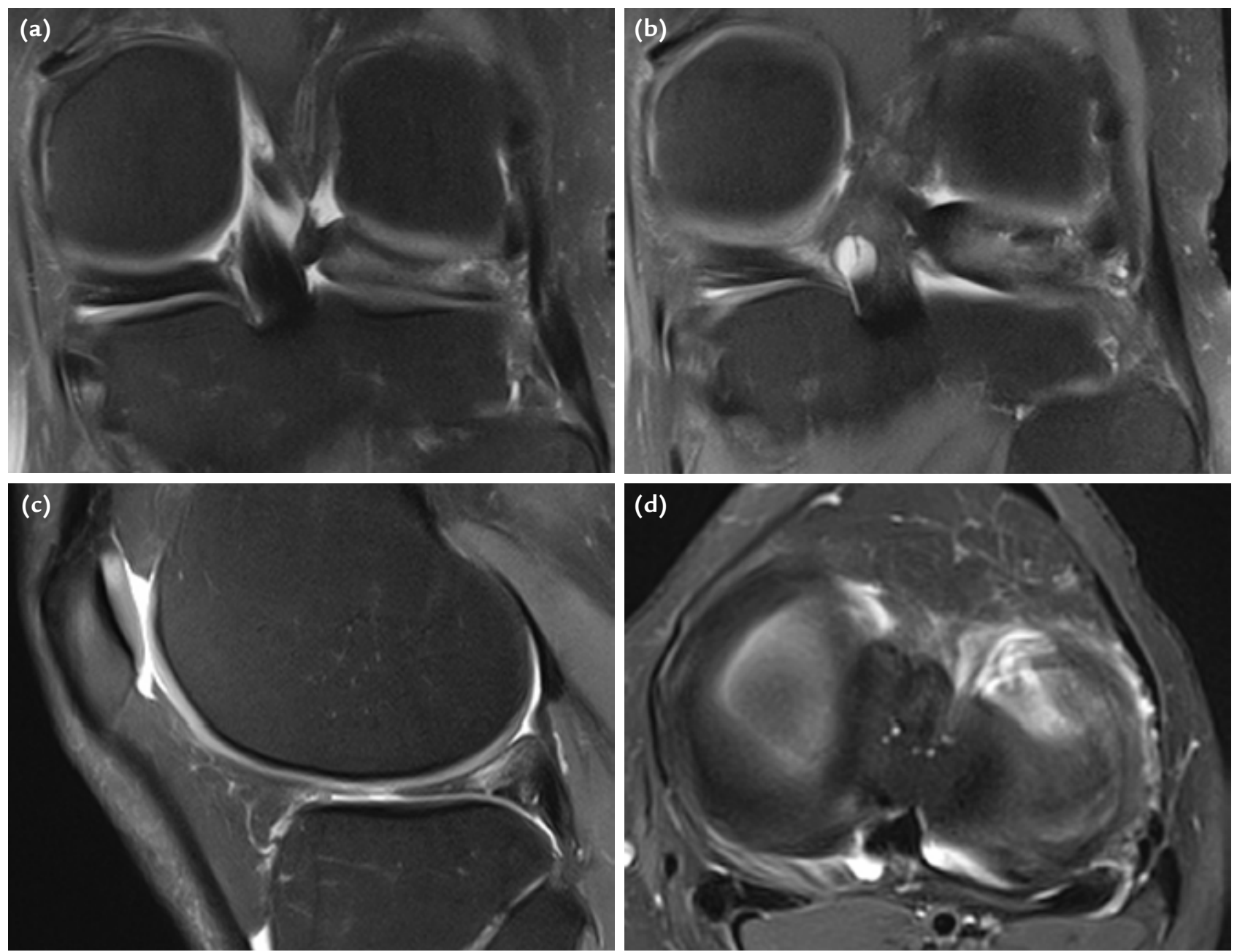

Şekil 1. a-d. Yirmi yedi yaşında kadın olgunun başvuru sırasındaki 3.0 Tesla MR incelemesi: lateral menisküs kompleks yırtığı.

kalitesinin iyi olmadığı greftler elendiğinden, menisküs allogrefti elde edilmesi ve temini zor bir dokudur. İdeal greft donörleri, 35 yaşın altındaki, enfeksiyon hastalığı öyküsü bulunmayan kadavralardır. ${ }^{[3]}$ Değişik saklama koşulları olsa da, greftin korunmasında en iyi sonuçlar taze greftler ile alınır. ${ }^{[14]}$ Çünkü, yaşamını sürdürebilen kondrosit popülasyonunun, ekstrasellüler matriksin sağlanması ve mekanik uyumun elde edilmesinde yararlı olduğu düşünülmektedir. ${ }^{[3]}$ Ancak, taze greftler dondurulmadığından, uzun süre saklanmamakta ve pratik bir kullanım olanağı bulunmamaktadır. Bu problem, kriyoprezervasyon ile güvenli ve fonksiyonel bir allogreft elde edilebilmesine olanak verecek şekilde çözülmüştür. Kriyoprezervasyonda greft gliserol içerisinde dondurulur. Ancak, bu yönteminde zorlukları ve pahalılığı nedeniyle, daha basit ve ucuz bir yöntem olan taze-dondurma yöntemi ön plana çıkmıştır. Dondurma işlemi, konnektif doku canlı hücrelerini yok etmekte ve histokompabilite antijenlerini ortadan kaldırarak immün cevap ihtimalini azaltmaktadır. ${ }^{[15]}$ Menisküsler asellüler olarak kabul edilseler de, histokompabilite antijenleri nedeniyle kriyoprezerve menisküs transplantasyonu sonrası rejeksiyon, bildirilen bir komplikasyondur. ${ }^{[16]}$ Bu yöntemde, greft steril koşullarda elde edildikten sonra -70 ila $-130^{\circ} \mathrm{C}$ 'de dondurularak depo edilir. Ancak, dondurma işlemi donör hücreleri yok edebilmekte ve greftin boyutunun küçülmesi sorunu görülebilmektedir. Bir diğer yöntem olan liyofilizasyonda ise, dondurma işlemine ek olarak doku dehidrate edilerek depolanır; ameliyat öncesi çözülerek rehidrate edilir. Bu yöntemin avantajı dokunun oda sıcaklığında saklanabilmesi olmakla birlikte, dokunun büzüşmesi ve HIV'in dokudan tam olarak uzaklaştırılamaması dezavantajlardır. ${ }^{[3]}$ Yaşamı tehdit edebilen bulaşıcı 

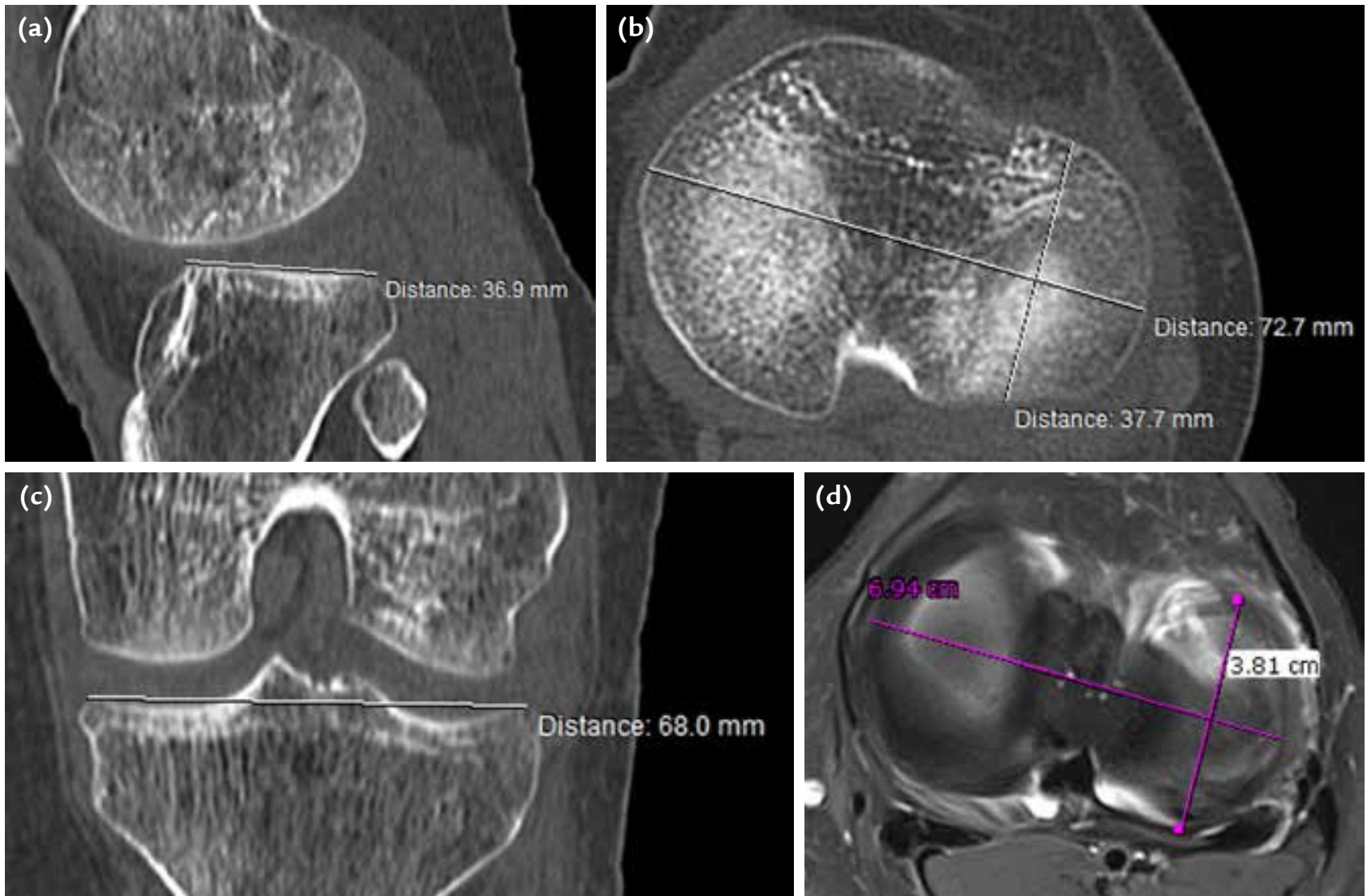

Şekil 2. a-d. Menisküs allogrefti talebi öncesi BT ve MR incelemelerindeki ölçümler.

hastalıkların varlığı, sekonder sterilizasyon tekniklerini ön plana çıkartmıştır. Üç temel teknik vardır: liyofilize etme, etilen oksit ve gama irradyasyon. Hazırlanması aşamasında hidrojen peroksit doku hasarına neden olduğundan, sinovit ve sinoviyal fibrozis gibi sorunlara yol açabildiğinden kullanılmamalıdır. Gama irradyasyon, allogreft dokusunun sterilizasyonunda en çok kullanılan yöntem olarak ön plana çıkar. ${ }^{[3]}$ MAT kararı verilen hastalarda allogreftin boyut seçimi için MR ve bilgisayarlı tomografi (BT) incelemelerinde ölçümler ve planlama yapılmalıdır. Sadece konvansiyonel radyografiler ile yapılan boyut ölçümlerinde $\% 8,4$ ya da 3,8 mm'ye kadar hata yapılabilir. ${ }^{[17]}$ Mediyal tibia platosunun genişliği, lateral tibia platosunun ön-arka mesafesi ve koronal planda lateral menisküsun genişliği, sagittal planda menisküsün genişliği ve ayrıca tibia platosunun ölçümleri değerlendirilir (Şekil 2). Ölçülemeyecek durumda olan menisküsler için karşı diz iyi bir alternatiftir. Yoon ve ark., 60 sağlıklı gönüllü üzerinde 3.0 Tesla MR çekimleri yaptıkları çalışmalarında, sağ ve sol menisküslerin boyutları arasında istatistiksel olarak anlamlı bir fark olmadığını bildirmişlerdir. ${ }^{[18]} \mathrm{Bu}$ ölçümler hastanın ihtiyacı olan menisküsün belirlenmesinde önemli olduğu kadar doku bankasının yapacağı ölçümler de önemlidir ve güvenilir olmalıdır. Çünkü, küçük seçilen bir menisküs allogrefti uygulandığında menisküse gelen yük fazla olur, erken dejenerasyonlar ve yırtıklar beklenir. Allogreft büyük uygulandığında ise tibia ve femur arasında kalamaz; dışarı çıkar, beklenen fonksiyonu gösteremez. ${ }^{[2]} \mathrm{Her}$ iki durumda da, menisküs transplantasyonunun revizyon ameliyatları gerekir. Allogreftin korunması da sonuçları etkileyebilecek bir diğer önemli etkendir. Allogreft taşınması sırasında soguk zincire dikkat edilmesi gereklidir. Temin edilecek firmanın da akredite bir firma olması tercih nedeni olmalıdır. ${ }^{[19]}$

\section{CERRAHI TEKNIK}

Lateral MAT için açık ve artroskopik çeşitli teknikler tanımlanmıştır. ${ }^{[20,21]}$ Ancak, morbiditeyi azaltmak ve ameliyat sonrası rehabilitasyonu kolaylaştırmak için artroskopik yöntemler daha uygundur. ${ }^{[3]}$ Lateral menisküs transplantasyonlarında, ön ve arka boynuzların 


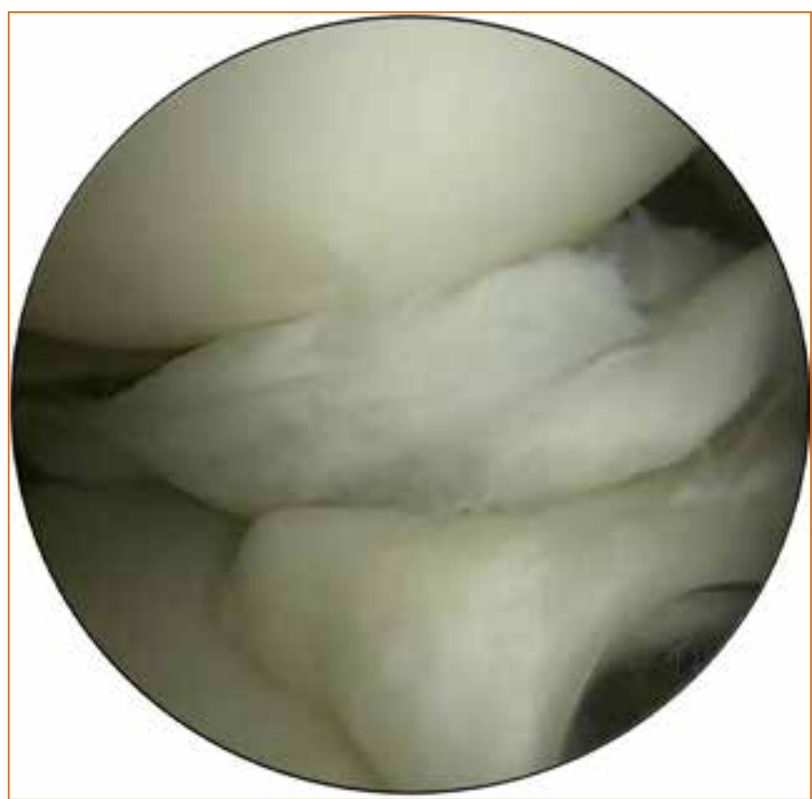

Şekil 3. Artroskopik değerlendirmede lateral menisküs kompleks yırtığı.

tibial yapışma yerlerinin yakın olması nedeniyle, tek kemik bloğu ile çalışma yapılmalıdır. Bu kemik bloğunun, doğru açı ile doğru yerde ve doğru büyüklükte hazırlanması gerekir. Kemik bloğun tibiaya oturacağı yuva artroskopik veya açık olarak hazırlanabilir. Menisküs transplantasyonlarında allogreft dokusunda kemik bloğu bırakılmasının en büyük avantajı, menisküslerin tibia platosuna yapışma yerlerinin çok özel olmasıdır. Bu bölgelerde, menisküs dokusunun ligamentöz yapıya, daha sonra da Sharpey liflerine dönüştüğü geçiş zonları vardır. Kemik bloğu kullanılmadığında, kemik-menisküs iyileşmesi ancak bir fibröz bağlantı ile sağlanır ve Sharpey lifleri kadar güçlü bir yapıya sahip olamaz. Kadavrada kemik bloğu olmadan yapılan nakil ile bloklu tekniği karşılaştıran Wang ve ark. da, transosseöz tespit tekniği ile kemik bloğun daha yüksek güç dağılımına sahip olduğunu, biyomekanik çalışmalarının sonucunda görmüşlerdir. ${ }^{[22]}$ Sekiya ve ark., klinik çalışmaları sonucunda, kemik tespitinin anlamlı ölçüde avantajlı olduğunu bildirmişlerdir. ${ }^{[21]}$ illk geliştirilen teknik "key hole" tekniğidir; burada, tibia slopuna paralel bir kılavuz K teli geçirildikten sonra, ACL ameliyatlarında kullanılan oyucu ile tibiaya bir tünel açılır ve bu tünelin üst kısmı eklemle birleştirilerek hazırlanan greft ve kemik bloğu kızak şeklinde içeri itilir. Teorik olarak incelendiğinde mümkün gibi gözükse de, pratik uygulamada patellar tendonun oluşturduğu engel nedeniyle lateralde çalışmak pek kolay olmaz. Bu teknik

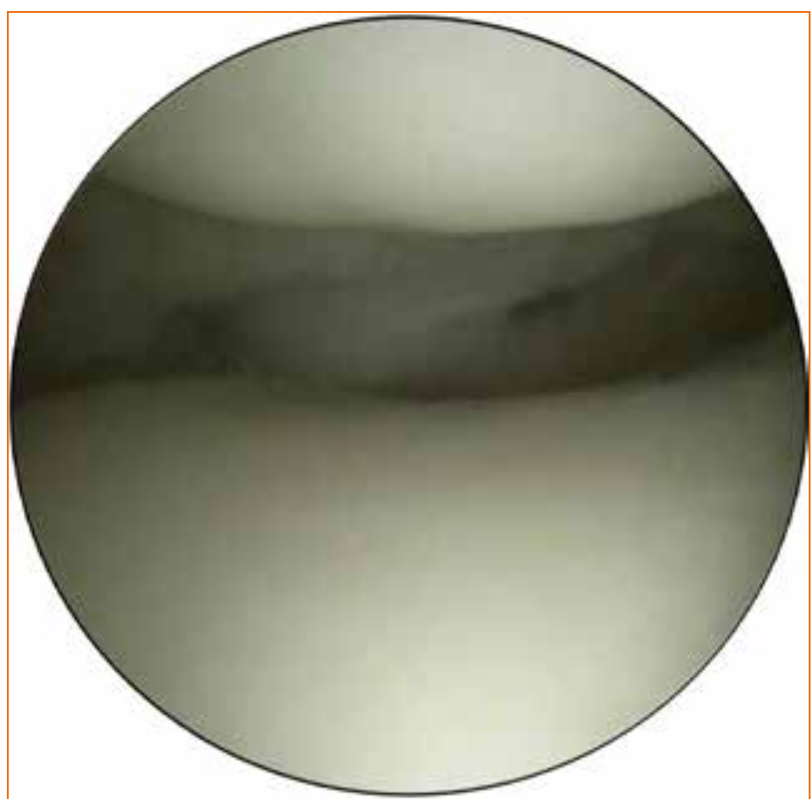

Şekil 4. Total menisektomi sonrası lateral kompartman.

daha sonradan modifiye edilmiş olsa ve blok daha köşegen bir yapı haline getirilerek uygulanmaya çalışılsa $\mathrm{da}$, patellar tendon anatomik komşuluğu ve oluşturduğu mekanik engel tekniği zorlaştırmaktadır.

\section{YAZARLARIN ÖNERDiĞi TEKNIK}

Hasta supin pozisyonda ameliyat masasına yatırılır. Standart anteromediyal ve anterolateral portallerden diz eklemine girilir. Eklemin tüm kompartmanları artroskopik olarak kontrol edilir (Şekil 3 ve 4). Lateral ve mediyal eklem aralığında olası osteofitlerin varlığı kontrol edilir ve varsa temizlenir. Eklem değerlendirildikten ve menisküs transplantasyonuna engel olmadığı anlaşıldıktan sonra, soğuk zincir ile getirilmiş olan menisküs allogrefti paketinden uygun şekilde çıkartılıp ıslak gaza sarılarak oda ısısında ısınmaya bırakılır (Şekil 5). Daha sonra, radyofrekans cihazı kullanılarak menisküsün ön ve arka boynuzlarının yapıştığı kemik dokunun üzerindeki yumuşak dokular temizlenir; bu temizlik burr tıraşlayıcı ile çalışmaya olanak sağlar. Artroskopik olarak burr tıraşlayıcı kullanılarak, bu bölgeye yaklaşık $7 \mathrm{~mm}$ eninde ve anteroposterior planda yeterli kemik dokusu bırakacak şekilde $1520 \mathrm{~mm}$ derinliğinde dikdörtgen prizması şeklinde bir yuva açılır (Şekil 6). Bu yuva, küçük osteotomlar ile ya da yuva şablonları ile köşegen hale getirilmeye çalışılır. Yuva açılımı bittikten sonra allogreft ısınmış olur. Menisküs allogreftinin 


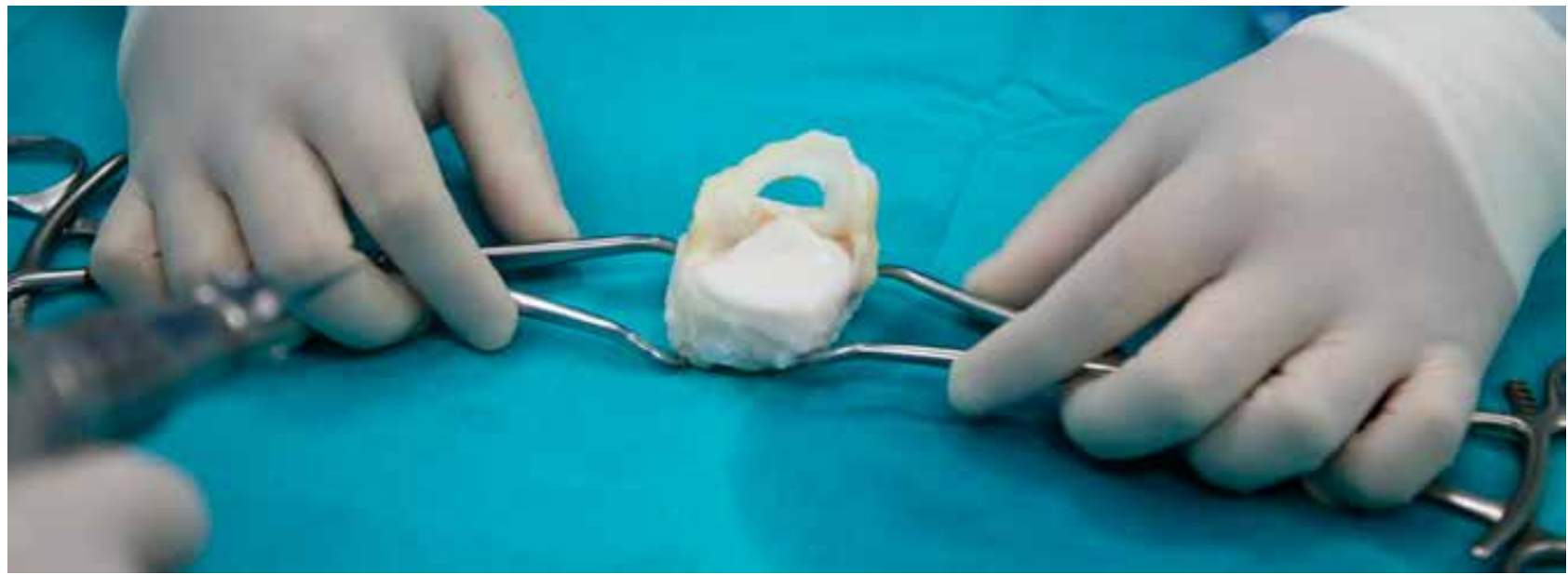

Şekil 5. Kemik bloklu lateral menisküs allogreftinin hazırlanma anı.

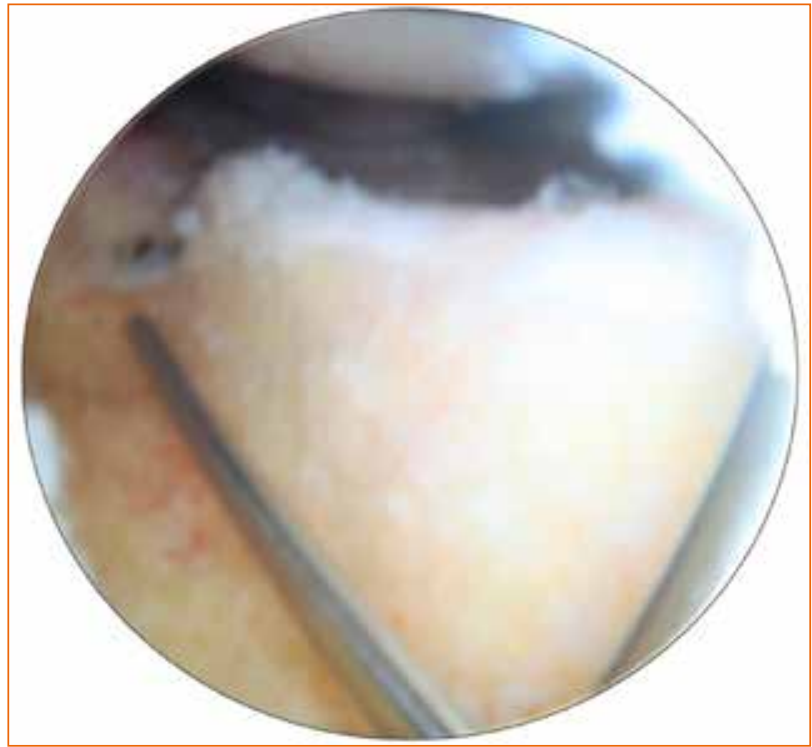

Şekil 6. Lateral menisküs ön ve arka boynuzlarının yapıştığı tibia plato bölgesine $7 \times 15-20 \mathrm{~mm}$ boyutlarında yuva açılmasını takiben boyutların kontrol edilmesi.

periferindeki yağ dokular öncelikle bir doku makası ile temizlenmelidir. Açılmış olan kemik yuvaya uyacak şekilde, allogreftin kemik bağlantıları korunarak kemik dokusu şekillendirilir (Şekil 7). Tibianın konveks yapısı göz önünde bulundurularak, allogreftin konveks eklem yüzeyinin en tepe noktasının arka ve önündeki kemik blokları yuvadakine göre ayarlanır. Kemik bloğuna 1,2 mm'lik K teli ile iki adet delik açılarak, 5 numara örgülü, absorbe olmayan polyester dikişler geçirilerek, greft hazır hale getirilir (Şekil 8). Ancak, artroskopik olarak açılan yuvada trans tibial olarak ilerletilecek rehber tellerin çıkışları allogreftin üzerindeki kemik tünellerin deliklerine birebir uymalıdır; bu amaçla, allogreftin ve tibia platosunun konveks kısımları rehber nokta olarak seçilmelidir. Hamstring tendonlarının distalinden bir kesi yapılır, ACL ameliyatında kullanılan yönlendirici ve driller ile iki adet $3 \mathrm{~mm}$ çapında tünel açılır, bu tünellerden menisküs dikiş iğnelerinin yardımı ile taşıyı ı sütürler geçirilerek anterolateral portalden dışarı alınır. İçeriden dişarıya teknik kullanılarak popliteus tendonunun anteriorundan da iki adet taşıyıcı sütür geçirilir (Şekil 9). Allogreftin kemik bloğundaki taşıyıcı sütürlere ek olarak popliteus tendonu izinin anteriorundan ve menisküsün anterior boynuzuna da iki taşıyıcı sütür anterolateral portalden yerleştirilir. Anteriordaki sütürün amacı, gerektiğinde menisküs allogreftini tekrar dışarı almak ve menisküs yerleştirildiğinde anterior tespitinin yapılmasını sağlamaktır. Daha sonra, anterolateral portal menisküs allogreftinin geçebileceği kadar genişletilir. Allogreftin kemik dokusunda ve popliteus tendonu komşuluğundaki askı sütürleri taşıyıcı sütürlere takılarak, menisküs allogrefti kontrollü bir şekilde artroskopik olarak eklem içerisine çekilir. Menisküs allogreftinin kemik ve yumuşak kısımları eklem içinde redükte edildikten sonra, kemik bloğun askı sütürleri tibianın anteromediyal korteksi üzerinde bağlanır (Şekil 10). Eklem içinde ise menisküsün posterior boynuzuna ve korpusuna, hepsi içeride menisküs dikiş tekniği ile kapsüle tespitleri sağlanır. Anteriorda ise taşıyıcı sütür anterior kapsüle sıkı olmayacak şekilde bağlanır. Eklem hareket açıklığında menisküs stabilitesi test edildikten sonra artroskopik kontrol yapılır. Kanama kontrolü sonrası, bir adet hemovak diren eklem içine yerleştirilir ve katlar anatomik olarak kapatılır. Hareketi engellemek için dizi ekstansiyonda tutan breys kullanılır. Ameliyat sonrası görüntüleme teknikleri ile greftin yerleşimi kontrol edilir (Şekil 11). 

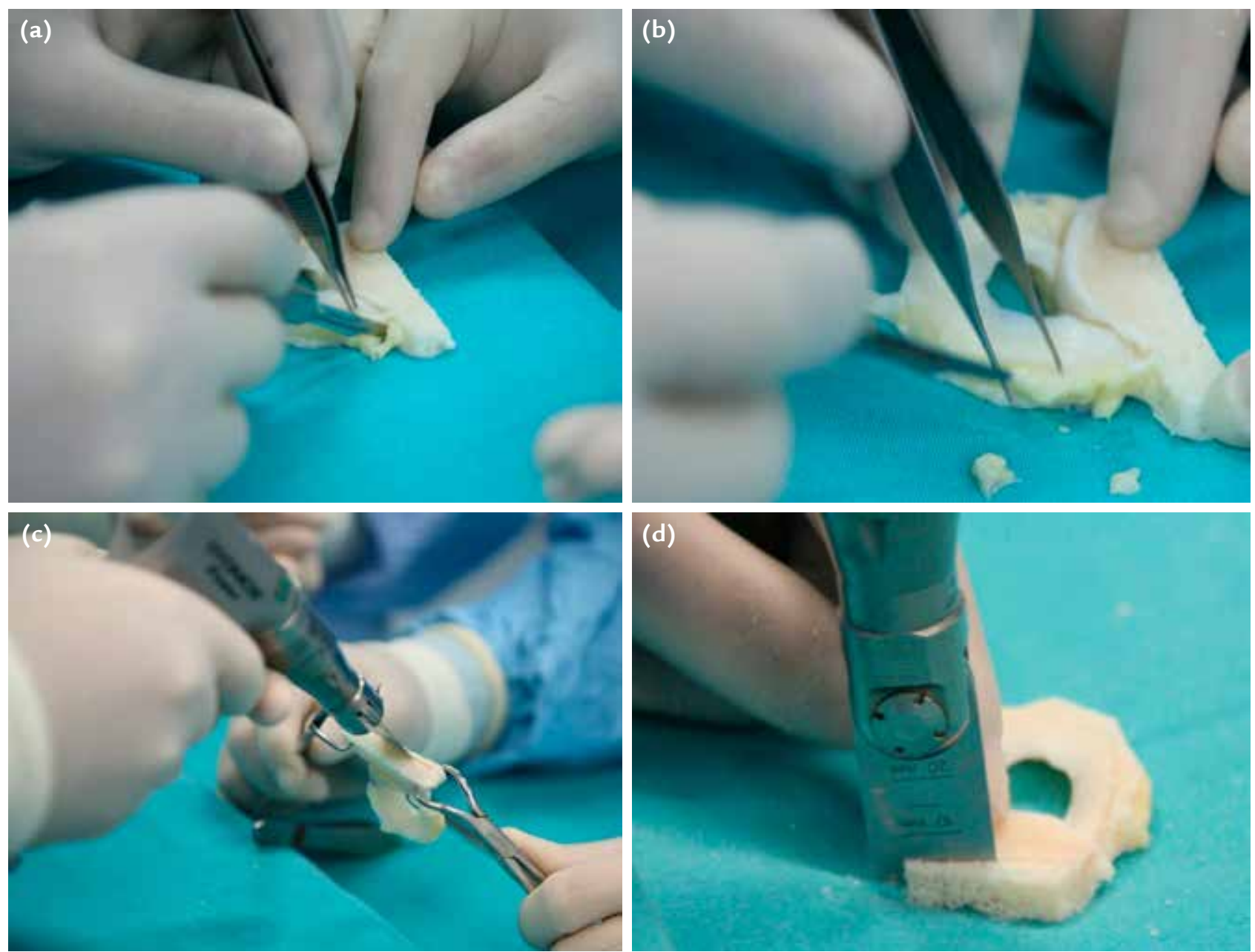

Şekil 7. a-d. Kemik bloklu lateral menisküs allogreftinin hazırlanma anı.

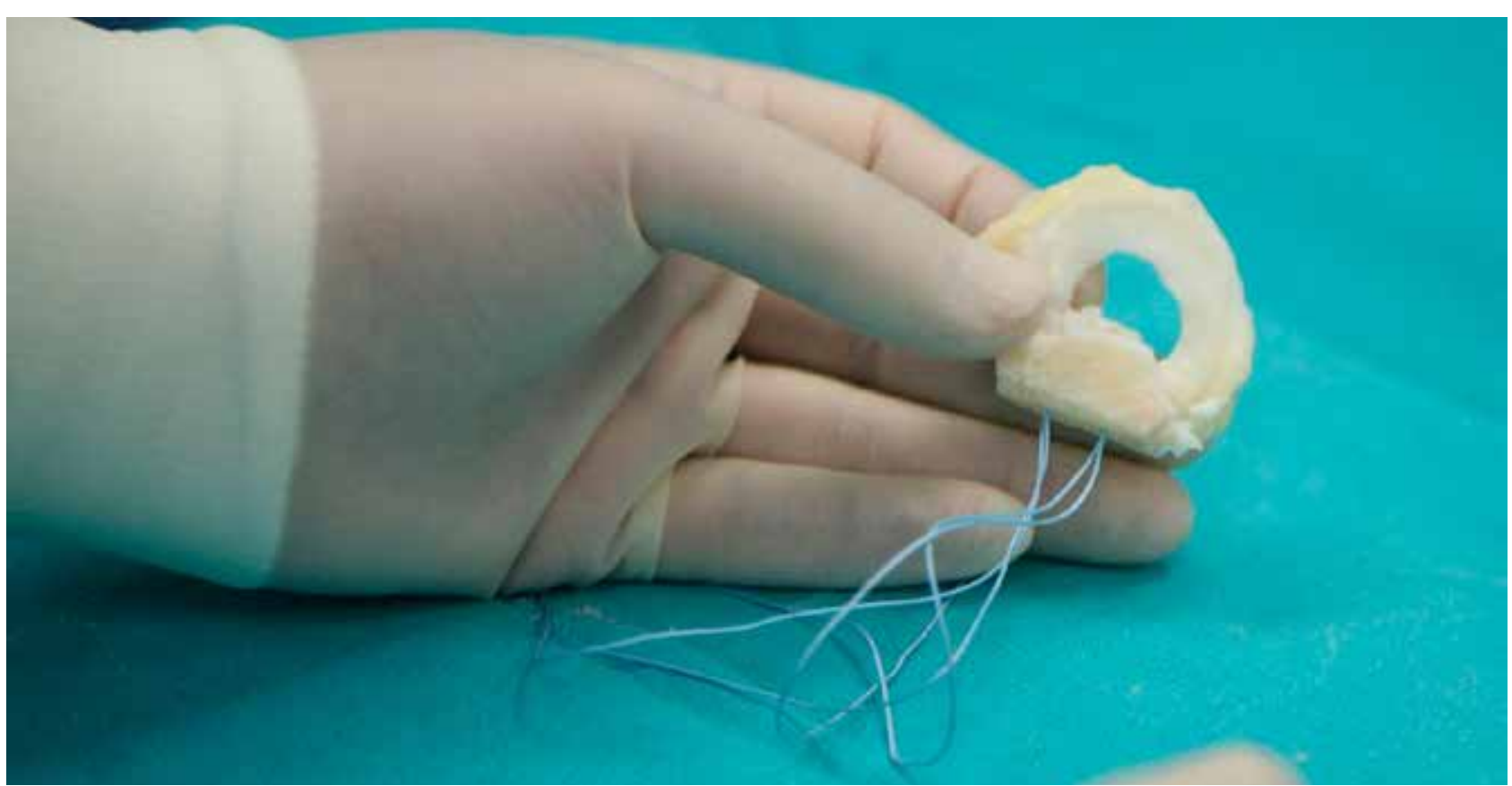

Şekil 8. Askı sütürü uygulaması sonrası transplantasyona hazır allogreft. 


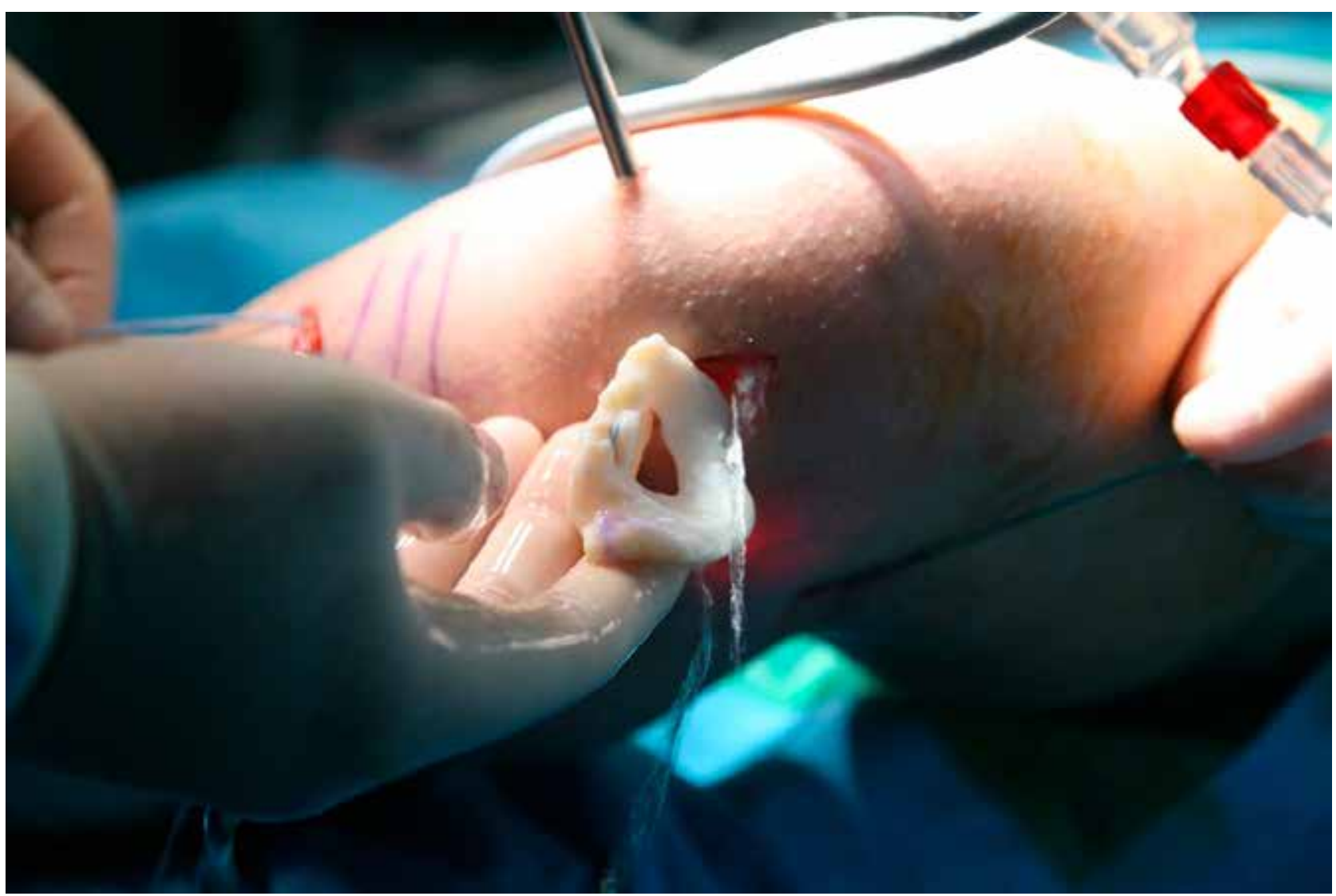

Şekil 9. Lateral menisküs allogreftinin ekleme yerleştirilme anı.

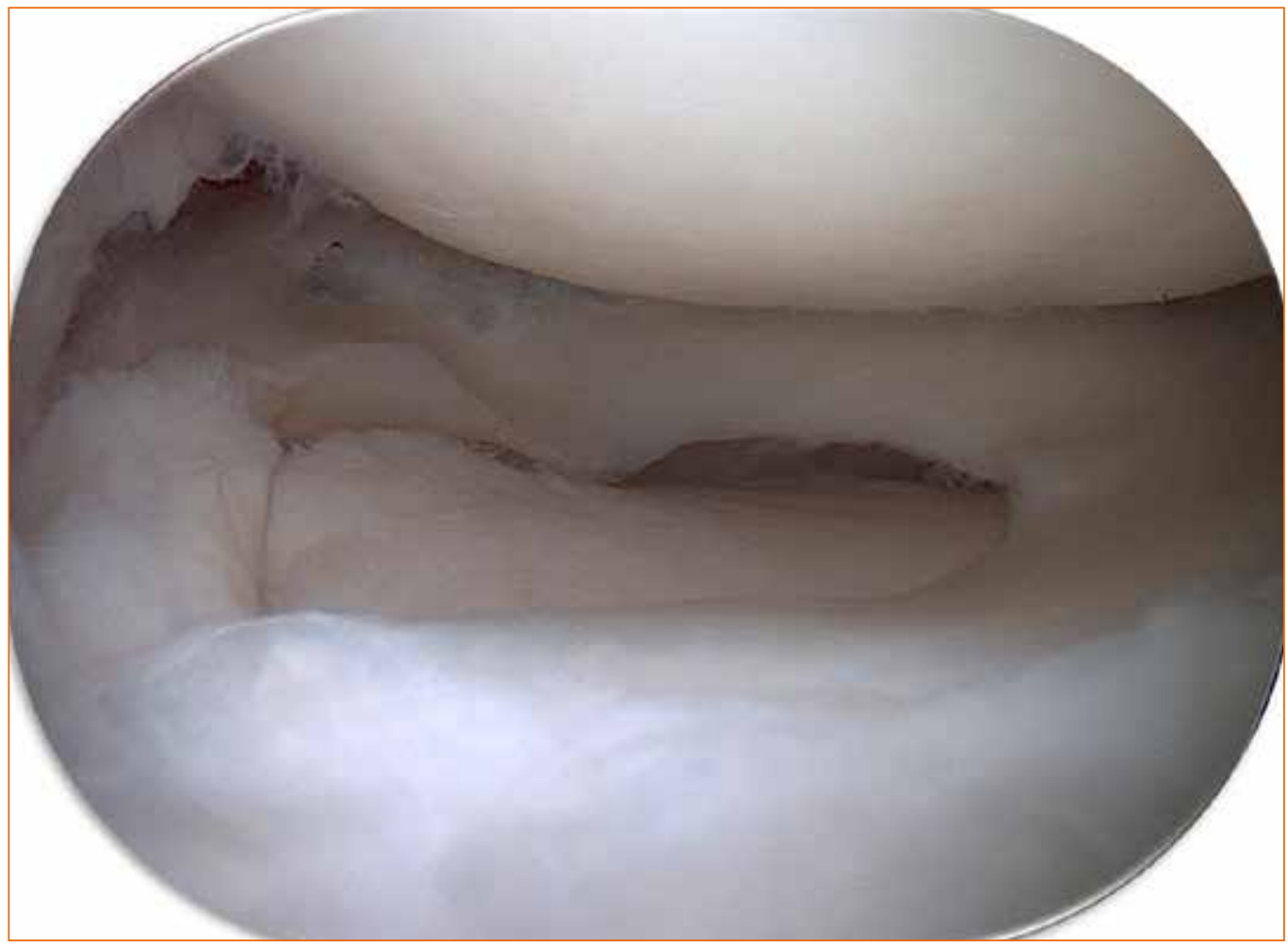

Şekil 10. Lateral menisküs allogrefti uygulama ve sütürlerin tespiti sonrası. 

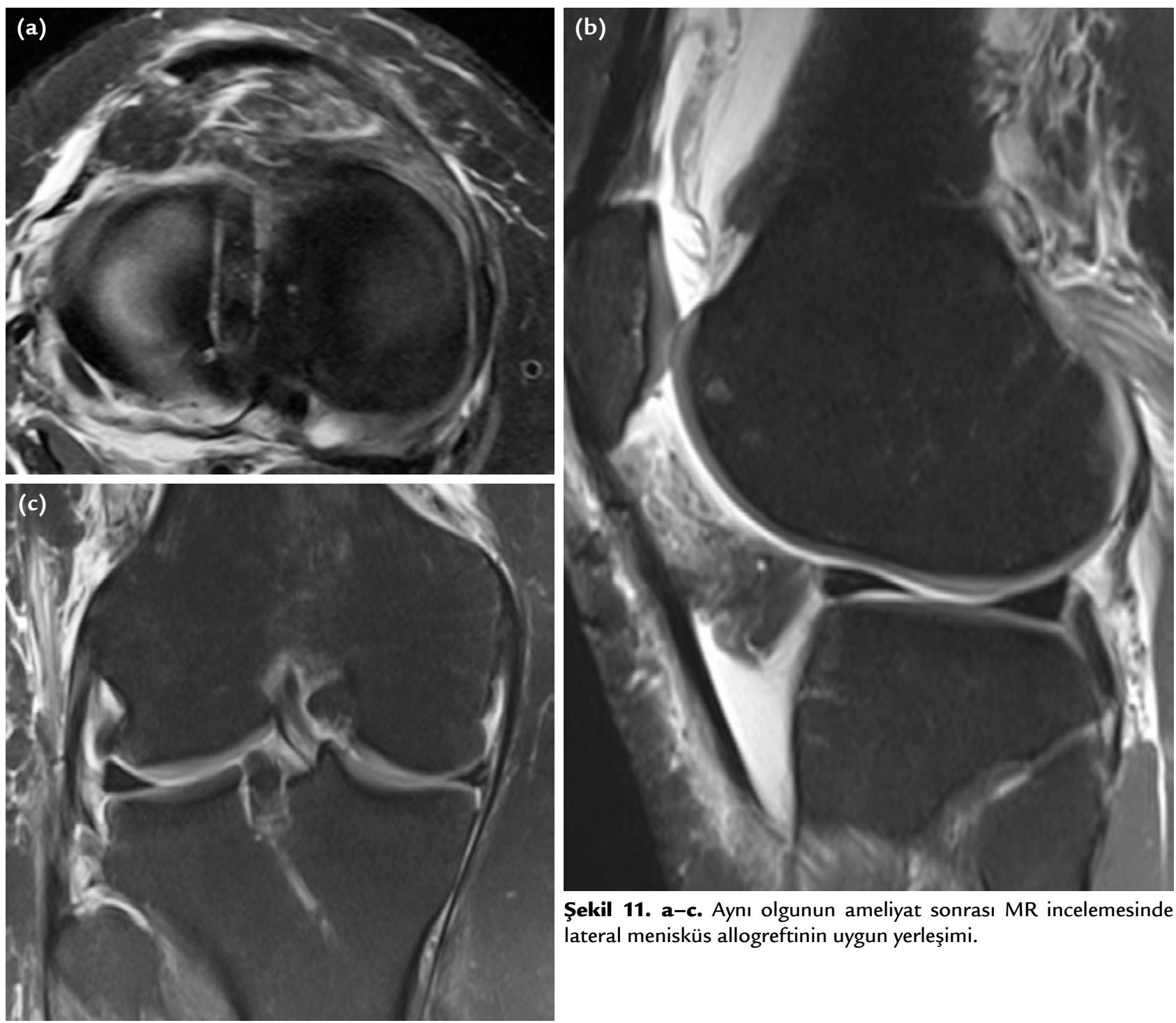

Şekil 11. a-c. Aynı olgunun ameliyat sonrası MR incelemesinde lateral menisküs allogreftinin uygun yerleşimi.

\section{REHABILITASYON}

Evrensel kabul görmüş bir rehabilitasyon protokolü olmasa da, rehabilitasyon genel olarak erken pasif hareket ile birlikte transplante edilen allogreftin korunması ve beslenmesini kolaylaştırmaya yöneliktir. Ameliyat sonrası ödemin geçmesi ile birlikte, hemen aktif ve pasif hareketlere başlanır. Illk bir aya kadar tedrici olarak $90^{\circ}$ fleksiyona izin verilir. Birinci aydan sonra, aktif fleksiyon sınırı kaldırılarak fleksiyona izin verilir. Tam ve pasif fleksiyona 4 . aydan sonra izin verilir. Ameliyattan bir ay sonra parsiyel yük verilir. Altısekiz hafta sonra tam yük verilebilir. Hastaların önceki aktivite düzeylerine dönmeleri ortalama 6-9 ayı bulmaktadır.

\section{KOMPLIKASYONLAR}

MAT'ın başlıca komplikasyonları enfeksiyon, venöz tromboemboli, artrofibrozis, diz hareketlerinde kısıtlılık gelişmesi gibi genel diz cerrahisi komplikasyonlarıken, doku uyumsuzlukları ve transplante edilen menisküs dokusunun yüksekliğinde azalma bu ameliyata özel olan akıldan çıkarılmaması gereken sorunlardır. Unutulmaması gereken en önemli nokta, ameliyat sırasında teknik bir zorluk ya da komplikasyon olduğunda elimizde sadece bir tek menisküs allogrefti bulunduğu gerçeğidir. MAT ameliyatı, ortopedide nadir yapılan bir ameliyat olması nedeniyle, kompleks diz rekonstrüksiyonu konusunda yeterli tecrübe ve deneyime sahip cerrahlar tarafindan yapılmalıdır. Ayrıca, olgularda 
diz ağrısı ya da diz ile ilgili yeni problemler oluştuğunda, değerlendirme MR ya da yeni bir artroskopi müdahalesi ile yapılmalıdır. ${ }^{[23]}$

\section{LITERATÜRE BAKIŞ VE ÇIKARIMLAR}

Menisküs transplantasyonları hakkında yapılan 44 çalışmanın meta-analizinin yapıldığı ElAttar ve ark. çalışmalarında, MAT'ın menisektomi yapılmış ve semptomları tedaviye dirençli olgularda güvenle uygulanabileceğini bildirmişlerdir. ${ }^{[24]}$ Çalışmalarında, hasta grubunu VAS, Lysholm ve Tegner aktivite skorları ile değerlendirmişlerdir. Menisektomiden sonra erken dönem ve semptomları başlayınca transplantasyon yapılan olgularının karşılaştırmalı sonuçlarını bildiren Jiang ve ark., erken yapılan transplantasyonda daha tatminkar ancak subjektif sonuçlar elde edildiğini, daha az eklem dejenerasyonu görüldüğünü ve kas gücü kaybının daha az olduğunu bildirmişlerdir. ${ }^{[25]}$ Verdonk ve ark.'nın uzun dönem geriye dönük analizlerinde, MAT cerrahisinin ağrıyı azalttı̆̆ı ve fonksiyonu iyileştirdiğini, potansiyel kondroprotektif etkisinin olduğunu bildirmişlerdir. ${ }^{[26]}$ Vundelinckx ve ark. ise uzun dönem olgu serileri sonuçlarında, MAT'ın tatmin edici, ağrıyı giderici ve fonksiyonel skorları koruyucu bir tedavi olduğunu bildirmişlerdir. ${ }^{[27]}$ Bir diğer önemli konu da, dejeneratif dizlerde menisküs allogreft transplantasyonu yapılması konusudur. Bu konuda 115 olguluk ciddi eklem kıkırdağı hasarılı hastaya meniskal allogreft transplantasyonu uygulamasının uzun dönem sonuçlarını yayımlayan Stone ve ark., 50 yaş üzerinde ve ileri evre kıkırdak hasarlı olgularda sonuçların kötü olması nedeniyle, MAT cerrahisinin genç olgularda tercih edilebileceğini bildirmişlerdir. ${ }^{[28]}$ Semptomatik, 50 yaş altındaki olgularda menisküs naklinin uzun dönem sonuçlarını bildiren Noyes'in çalışmasında, 10 yıllık dönemde \%63 olguda yeterli sonuç elde edilirken, 15 yılda bu oranın \%43'e düştüğü bildirilmiştir. Bu sonucun elde edilmesinde kriyoprezerve transplant kullanımının önemli bir faktör olduğunu belirtmişlerdir. ${ }^{[29]}$ Menisküslerimizin sentetik implantlar ile replase edildiği tedavi yöntemlerinin uzun dönem takip sonuçlarının olmaması, implantları skafold olarak kullanıp hücre destekli uygulamaların başlaması nedeniyle, bu alanda halen araştırmalar yoğun olarak devam etmektedir. ${ }^{[14]}$ Menisküs allogreft transplantasyonu, uygun endikasyonlarda uygulandığında faydalı ve diz eklemini koruyan bir prosedürdür. Ancak, henüz daha araştırmaların devam ettiği bir aşamadadır. Şu anki kanıt düzeyinde, genç ya da orta yaşlı, diz ağrılı erken dönem artrozlu menisektomili hastalarda kısa ve orta dönemde uygulanabilecek bir cerrahi tedavidir. ${ }^{[9,20,21,30]}$ Uzun dönem sonuçlarının bildirilmesi ve karşılaştırmalı çok merkezli ileriye dönük çalışmalar ile kanıt düzeyinin yükseltilmesi sonrası, MAT'ın daha yaygın ve standart bir tedavi olarak diz cerrahisinde yer alacağını düşünmekteyiz.

\section{KAYNAKLAR}

1. Fox AJS, Wanivenhaus F, Burge AJ, Warren RF, Rodeo SA. The human meniscus: A review of anatomy, function, injury, and advances in treatment. Clin Anat 2015;28(2):269-87. Crossref

2. Frank RM, Cole BJ. Meniscus transplantation. Curr Rev Musculoskelet Med 2015;8(4):443-50. Crossref

3. Johnson DL, Bealle D. Meniscal allograft transplantation. Clin Sports Med 1999;18(1):93-108. Crossref

4. Smith NA, Costa ML, Spalding T. Instructional review: Knee Meniscal allograft transplantation: Rationale for treatment. Bone Joint J 2015;97-B(5):590-4. Crossref

5. Ahmed AM, Burke DL. In-vitro measurement of static pressure distribution in synovial joints - Part I. Tibial surface of the knee. J Biomech Eng 1983;105(3):216-25. Crossref

6. Baratz ME, Fu FH, Mengato R. Meniscal tears: the effect of meniscectomy and of repair on intraarticular contact areas and stress in the human knee. A preliminary report. Am J Sports Med 1986;14(4):270-5. Crossref

7. Lubowitz JH, Verdonk PC, Reid JB, Verdonk R. Meniscus allograft transplantation: A current concepts review. Knee Surg Sports Traumatol Arthrosc 2007;15(5):476-92. Crossref

8. Milachowski, KA, Weismeier K, Wirth CJ. Homologous meniscus transplantation. Experimental and clinical results. Int Orthop 1989;13(1):1-11. Crossref

9. Rosso F, Bisicchia S, Bonasia DE, Amendola A. Meniscal Allograft Transplantation: A Systematic Review. Am J Sports Med 2015;43(4):998-1007. Crossref

10. LaPrade RF, Wills NJ, Spiridonov SI, Perkinson S. A prospective outcomes study of meniscal allograft transplantation. Am J Sports Med 2010;38(9):1804-12. Crossref

11. Binnet MS, Akan B, Kaya A. Lyophilised medial meniscus transplantations in ACL-deficient knees: A 19-year follow-up. Knee Surg Sports Traumatol Arthrosc 2012;20(1):109-13. Crossref

12. GürS, JanousekAT, Fu FH. Allogreft menisküs transplantasyonu, (I), Acta Orthop Traumatol Turc 1997;31:429-36.

13. Shelbourne KD, Gray T. Results of anterior cruciate ligament reconstruction based on meniscus and articular cartilage status at the time of surgery. Five- to fifteen-year evaluations. Am J Sports Med 2000;28(4):446-52. Crossref

14. Verdonk R, Volpi P, Verdonk P, Van Der Bracht H, Van Laer M, Almqvist KF, Vander Eecken S, Prospero E, Quaglia A. Indications and limits of meniscal allografts. Injury 2013;44(Suppl 1):S21-7. Crossref

15. Brown KL, Cruess RL. Bone and cartilage transplantation in orthopaedic surgery. A review. J Bone Joint Surg Am 1982;64(2):270-9. Crossref

16. Hamlet W, Liu SH, Yang R. Destruction of a cryopreserved meniscal allograft: A case for acute rejection. Arthroscopy 1997;13(4):517-21. Crossref

17. Pollard ME, Kang Q, Berg EE. Radiographic sizing for meniscal transplantation. Arthroscopy 1995;11(6):684-7. Crossref

18. Yoon JR, Jeong HI, Seo MJ, Jang KM, Oh SR, Song S, Yang JH. The use of contralateral knee magnetic resonance imaging to predict meniscal size during meniscal allograft transplantation. Arthroscopy 2014;30(10):1287-93. Crossref 
19. Barron DJ, Khan NE, Jones TJ, Willets RG, Brawn WJ. What tissue bankers should know about the use of allograft heart valves. Cell Tissue Bank 2010;11(1):47-55. Crossref

20. Rijk PC. Meniscal allograft transplantation - Part I. Background, results, graft selection and preservation, and surgical considerations. Arthroscopy 2004;20(7):728-43. Crossref

21. Sekiya JK, West RV, Groff YJ, Irrgang JJ, Fu FH, Harner CD. Clinical Outcomes Following Isolated Lateral Meniscal Allograft Transplantation. Arthroscopy 2006;22(7):771-80. Crossref

22. Wang $\mathrm{H}$, Gee AO, Hutchinson ID, Stoner K, Warren RF, Chen TO, Maher SA. Bone Plug Versus Suture-Only Fixation of Meniscal Grafts: Effect on Joint Contact Mechanics During Simulated Gait. Am J Sports Med 2014;42(7):1682-9. Crossref

23. Oh KJ, Sobti AS, Yoon JR, Ko YB. Current status of secondlook arthroscopy after meniscal allograft transplantation: review of the literature. Arch Orthop Trauma Surg 2015;135(10):1411-8. Crossref

24. ElAttar M, Dhollander A, Verdonk R, Almqvist KF, Verdonk $P$. Twenty-six years of meniscal allograft transplantation: Is it still experimental? A meta-analysis of 44 trials. Knee Surg Sports Traumatol Arthrosc 2011;19(2):147-57. Crossref
25. Jiang D, Ao YF, Gong X, Wang YJ, Zheng ZZ, Yu JK. Comparative Study on Immediate Versus Delayed Meniscus Allograft Transplantation: 4- to 6-Year Follow-up. Am J Sports Med 2014;42(10):2329-37. Crossref

26. Verdonk PCM, Verstraete KL, Almqvist KF, De Cuyper K, Veys EM, Verbruggen G, Verdonk R. Meniscal allograft transplantation: Long-term clinical results with radiological and magnetic resonance imaging correlations. Knee Surg Sports Traumatol Arthrosc 2006;14(8):694-706. Crossref

27. Vundelinckx B, Vanlauwe J, Bellemans J. Long-term Subjective, Clinical, and Radiographic Outcome Evaluation of Meniscal Allograft Transplantation in the Knee. Am J Sports Med 2014;42(7):1592-9. Crossref

28. Stone KR, Adelson WS, Pelsis JR, Walgenbach AW, Turek TJ. Long-term survival of concurrent meniscus allograft transplantation and repair of the articular cartilage: A prospective two- to 12-year follow-up report. J Bone Joint Surg Br 2010;92-B(7):941-8. Crossref

29. Noyes FR, Barber-Westin SD. Meniscal Transplantation in Symptomatic Patients Under Fifty Years of Age: Survivorship Analysis. J Bone Joint Surg 2015;97(15):1209-19. Crossref

30. Matava MJ. Meniscal allograft transplantation: A systematic review. Clin Orthop Relat Res 2007;455:142-57. Crossref 